\title{
The effect of orientation and shape distribution of gravel on slope angles in central Taiwan
}

\author{
Hongey Chen ${ }^{\mathrm{a}, \mathrm{b}, *}$, Jui-Pin Wan ${ }^{\mathrm{a}}$ \\ ${ }^{a}$ Department of Geosciences, National Taiwan University, No. 1, Section 4, Roosevelt Road, Taipei, Taiwan, ROC \\ ${ }^{\mathrm{b}}$ Department of Earth Sciences, University of Cambridge, Downing Street, Cambridge CB2 3EQ, UK
}

Received 16 October 2002; accepted 23 June 2003

\begin{abstract}
We compare gravel orientation and slope angle distribution to highlight their possible relationship with various gravel shapes in the Ninety-Nine Peaks area in central Taiwan. In the study area, four gravel shapes - disk, equant, bladed, and roller-are collected and studied. Disk and equant shapes comprise more than $65 \%$ of the gravel. Eighty-five percent weight of gravel particles is composed of quartz sandstone. Sand particles only make up $14 \%$ of the matrix. The matrix strength ranges from 100 to $250 \mathrm{~kg} / \mathrm{cm}^{2}$. The slope angle ranges from $60^{\circ}$ to $70^{\circ}$, and more than $50 \%$ of the study area consists of such slopes. Linear regression analysis shows that when the proportion of disk, bladed, and roller shapes in the gravel increases, the slope angle increases, although the linear relationship remains indistinct. An important inverse relationship is that as the proportion of equant shapes in the gravel increases, the slope angle clearly performs differently by decreasing. The results of the investigation also show that the slope angle is lower when the imbrication direction of the gravel is parallel to the slope surface.
\end{abstract}

(C) 2003 Elsevier B.V. All rights reserved.

Keywords: Gravel orientation; Imbrication direction; Gravel shape; Slope angle

\section{Introduction}

The Ninety-Nine Peaks area lies at average elevation $700 \mathrm{~m}$ a.s.l and covers an area of 15 $\mathrm{km}^{2}$. This area is located within the southeastern portion of Taichung County in central Taiwan. The Ninety-Nine Peaks area is composed mainly of Quaternary and late Pleistocene gravel and has

* Corresponding author. Department of Geosciences, National Taiwan University, No. 1, Section 4, Roosevelt Road, Taipei, Taiwan, ROC. Tel.: +886-2-23636994; fax: +886-2-23636095.

E-mail address: hchen@ccms.ntu.edu.tw (H. Chen). suffered a series of landslides since the Chi-Chi earthquake $\left(M_{\mathrm{L}}=7.3\right)$ on 21 September 1999. We witnessed a cloud of dust and a large number of landslides during aftershock period, in particular, one with a magnitude of 6.8 , which occurred at 7:52 a.m. on 26 September (Fig. 1). The mountain slopes in the area (Fig. 2) display the various relationships between gravel orientation, grain shapes, and slope angle. [In this paper, gravel is defined as including only irregular ovoid-shaped materials ranging from 4.75 to $300 \mathrm{~mm}$ in size, in accordance with the definition given in the Unified Soil Classification System (Wagner, 1957).] 

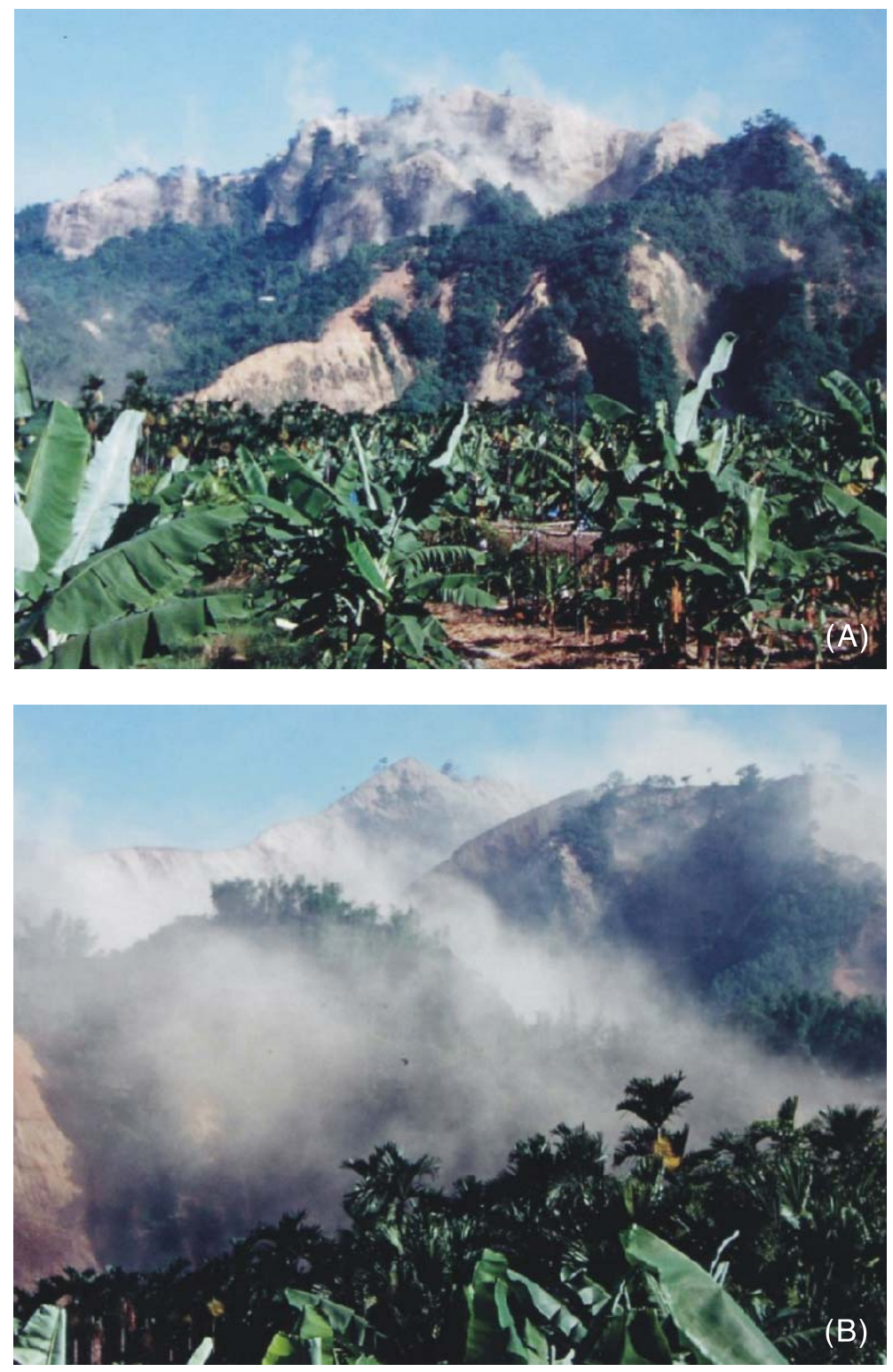

Fig. 1. New landslide occurring during the period of an aftershock $\left(M_{\mathrm{L}}=6.8\right)$ on 26 September 1999. (A) Dust was triggered at the onset of the landslide during the earthquake. (B) Enlargement of top left from (A). Cloud of dust appeared in the air while the great mass was sliding down the slope $10 \mathrm{~s}$ after the earthquake.

Tsai (1996) pointed out that gravel orientation has a higher anisotropy as the slope gradient changes. Therefore, when grain orientation is random, the gravel is more isotropic. The experimental results of Vallejo and Mawby (2000) show that when the concentration by weight of granular material in rock-soil mixture is greater than $75 \%$, the shear strength of the mixture is governed by the frictional resistance of the granular phase. Field results also demonstrate that the gravel shape and orientation still effect slope gradient even when the matrix 


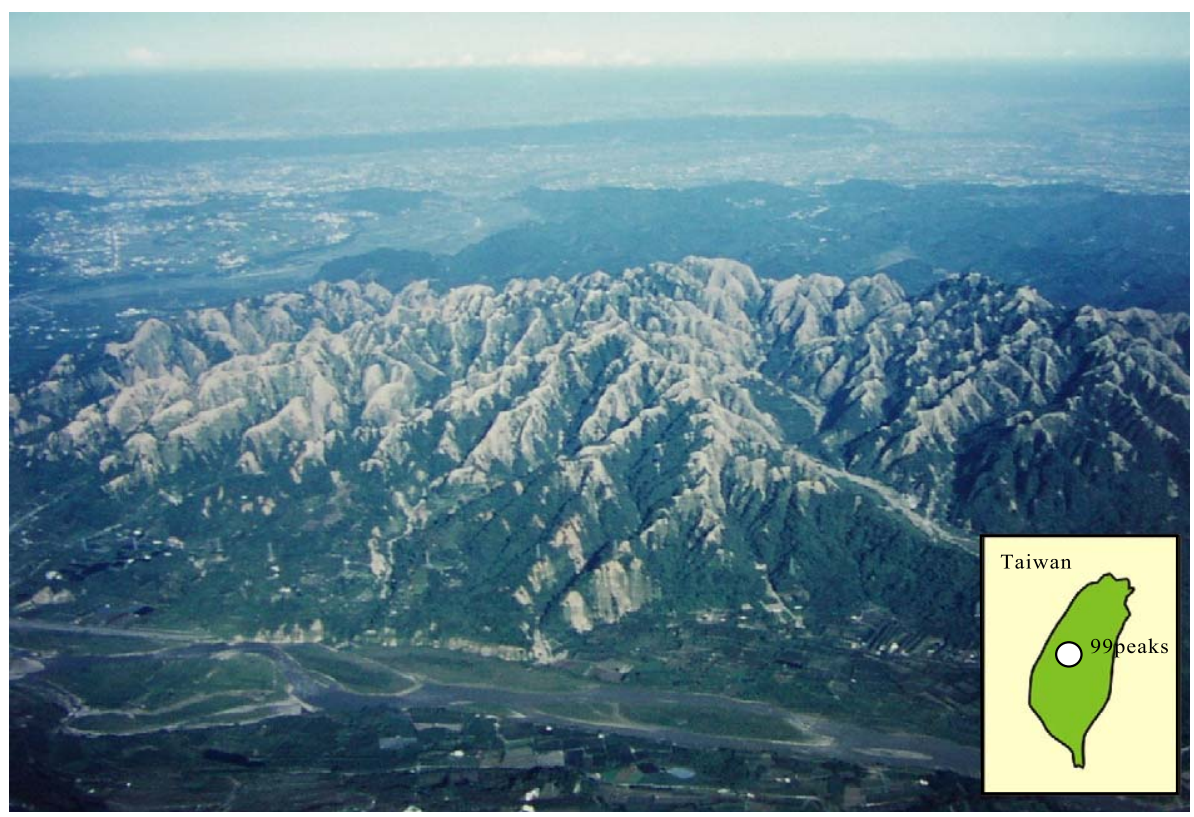

Fig. 2. Aerial view of the study area.

strength is constant (Wang, 2001). This means that when the gravel content is less than $70 \%$ weight in a matrix-supported formation, different gravel shapes and orientation can affect the stability of the gravel slope (Chen and Tsai, 2002).

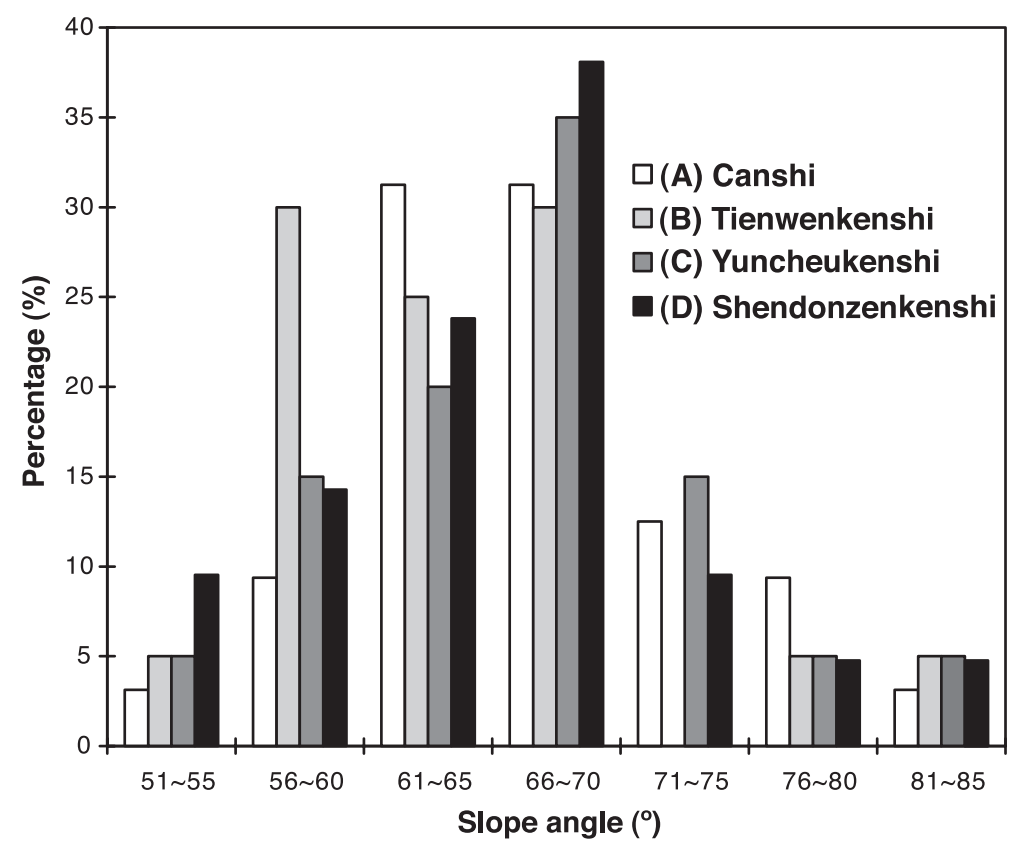

Fig. 3. The slope angle ranges from $60^{\circ}$ to $70^{\circ}$ and represents more than $50 \%$ in the study area. 
This paper will investigate the effects of gravel shape and orientation on slope angle along four brooks in this landslide-prone area: Canshi, Tienwenkenshi, Yuncheukenshi, and Shendonzekenshi.

\section{Geological setting and slope morphology}

The study area is mainly composed of the Huoyenshan Conglomerate Member of the Pleisto-
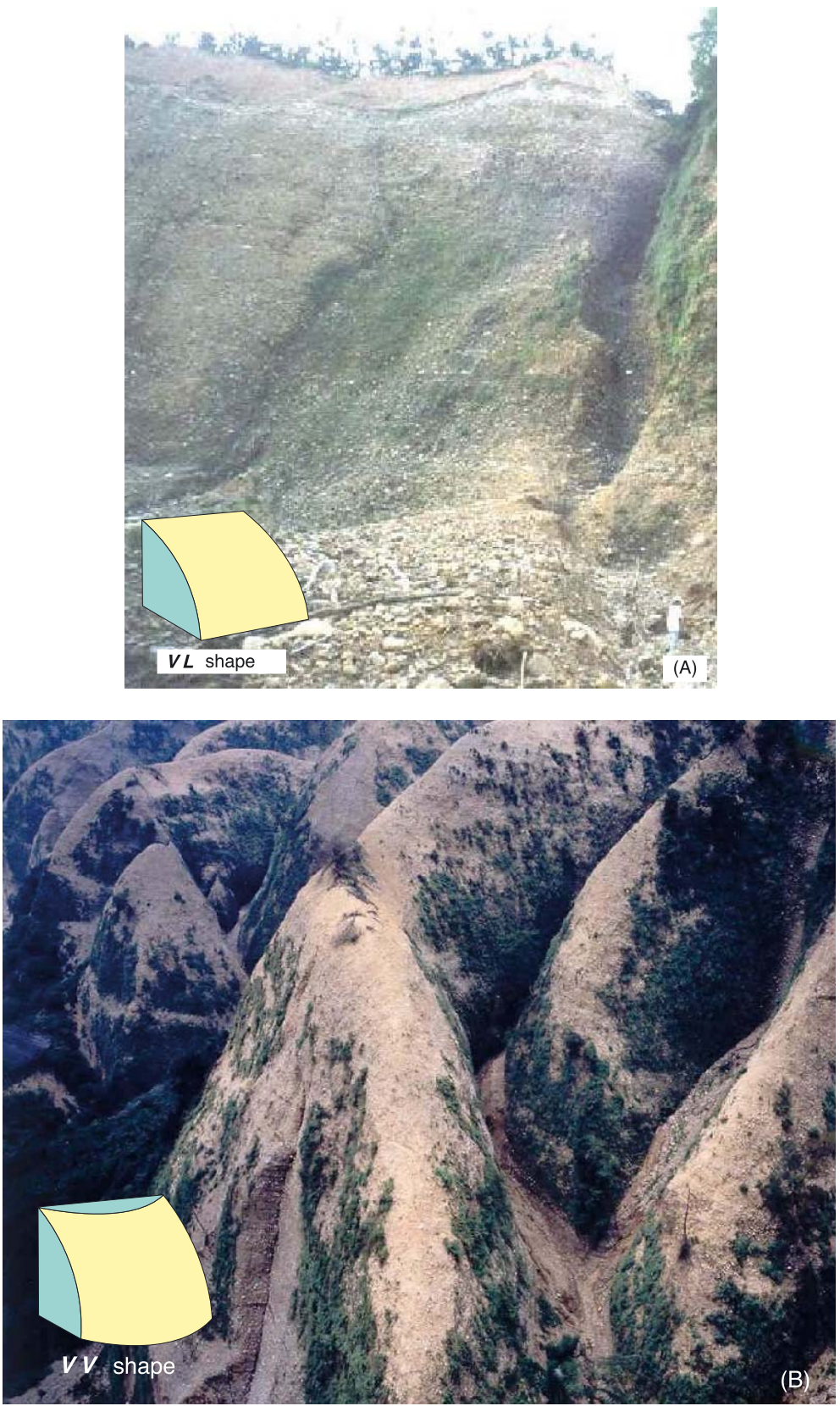

Fig. 4. Morphology of the two different shaped types of hillslopes, which can be classified following Ruhe (1975). (A) A VL-shaped hillslope appears on the downstream at most sites. The runoff channel in the central part was caused by gradual erosion. (B) A VV-shaped hillslope usually appears in the middle or upper stream parts of the study area. 
cene Toukoshan Formation (Ho, 1986). The Toukoshan Formation forms the lower parts of the Pleistocene-Quaternary in Taiwan (Chou, 1977). These formations are distributed mainly in the western foothills and plains of the Taiwan belt (Teng, 1996). The Toukoshan Formation is interpreted to have been deposited in a fluvial, shoreface, and shallow-marine environment (Chen and Teng, 1990). The formation is composed mainly of grayish-white to yellowish-gray hard sandstone and of gray to dark-gray shale and conglomerate. Sorting is poor, and the cementation is not loose. The thickness ranges from 1000 to $1500 \mathrm{~m}$. The conglomerate clasts are composed mainly of quartzite and are rounded to subrounded in shape, ranging in size from 0.1 to $1 \mathrm{~m}$. The matrix composition is predominately fine sand. The Pleistocene Huoyenshan Conglomerate has a grain-supported structure with large boulders floated within the fine fractions. Such matrix-supported structures normally form when a great volume of boulders enters the turbid regime (Nemec and Steel, 1984).

Ridges shape the Ninety-Nine Peaks area. The elevation ranges from 700 to $300 \mathrm{~m}$, with slopes radiating from the central parts outward. Our investigation covers the four brooks Canshi, Teinwenken- shi, Yuncheukenshi, and Shendonzekenshi. The minimum slope angle is $52^{\circ}$, with over $50 \%$ of slopes between $60^{\circ}$ and $70^{\circ}$, and some slopes as high as $85^{\circ}$ (Fig. 3).

The morphology of hillslope classification in terms of the three-dimensional features of the study area mainly includes doubly convex (VV) and convexlinear (VL) types (Ruhe, 1975). Fig. 4 shows the various geometric forms of both types of hillslopes in the study area.

Canshi brook is in the western part of study area. The slope height ranges from 150 to $250 \mathrm{~m}$. The hillslopes on the lower parts are of both VV and VL types (Table 1). The hillslopes on the upper parts are mainly of the VV types. Tienwenkenshi brook hillslopes are mostly VL types, with slope height ranging from 50 to $80 \mathrm{~m}$. The $\mathrm{V}$ shape of the gullies is the distinguishing characteristic of this brook. Yuncheukenshi brook is in the western part of the study area. The hillslopes along this brook are mostly of the VL types also, with slope height ranging from 70 to $150 \mathrm{~m}$. Shendonzekenshi brook is in the northern part of the area. The hillslopes in this area are all of the VV types, and the slope height ranges from 70 to $150 \mathrm{~m}$. Throughout the area, the VL type is mostly distributed in the

Table 1

Morphological characteristics of the study area

\begin{tabular}{|c|c|c|c|c|c|c|c|}
\hline Study area & & $\begin{array}{l}\text { Width } \\
(\mathrm{m})\end{array}$ & $\begin{array}{l}\text { Slope } \\
\text { grade }\left({ }^{\circ}\right)\end{array}$ & $\begin{array}{l}\text { Height } \\
(\mathrm{m})\end{array}$ & $\begin{array}{l}\text { Slope } \\
\text { shape }^{\text {a }}\end{array}$ & $\begin{array}{l}\text { Gully } \\
\text { type }\end{array}$ & Characteristics \\
\hline \multirow[t]{2}{*}{ Canshi } & downstream & 250 & $1-3$ & $50-100$ & VL & $\mathrm{U}$ & Much vegetation in the downstream gully. Most of \\
\hline & midstream & 200 & $3-5$ & $180-250$ & VV & $\mathrm{U}$ & $\begin{array}{l}\text { gully is } U \text { type and the tributary flow in northeast } \\
\text { direction. There are obvious changes on the slope } \\
\text { height and shapes along the gully. }\end{array}$ \\
\hline \multirow[t]{2}{*}{ Shendonzekenshi } & downstream & 250 & $1-3$ & $50-80$ & VL & $\mathrm{U}$ & The plants flourish on both riversides of downstream \\
\hline & midstream & 120 & $3-5$ & $180-200$ & $\mathrm{VV}$ & $\mathrm{U}$ & $\begin{array}{l}\text { Two large lobes were left deposited on the gully and } \\
\text { formed some alluvial fans. The gully width becomes } \\
\text { small from the middle to the upper stream. }\end{array}$ \\
\hline \multirow[t]{2}{*}{ Tienwenkenshi } & downstream & 40 & $15-20$ & $50-80$ & VL & $\mathrm{V}$ & A lot of deposited material covered on the gully. \\
\hline & midstream & 40 & $15-20$ & $50-80$ & VL & $\mathrm{V}$ & $\begin{array}{l}\text { Most of gully is } \mathrm{V} \text { type. Both sidewalls have a lot } \\
\text { of plants. The top of slope is barren. It has no } \\
\text { changes between the middle and downstream. }\end{array}$ \\
\hline \multirow[t]{2}{*}{ Yuncheukenshi } & downstream & 50 & $15-20$ & $50-80$ & VL & V & Major feature was massive deposition on the gully. \\
\hline & midstream & 50 & $15-20$ & $50-80$ & VL & $\mathrm{V}$ & $\begin{array}{l}\text { Some of plants grow at the toe of slope. The top } \\
\text { of slope is also bold. It has no changes between } \\
\text { the middle and downstream. }\end{array}$ \\
\hline
\end{tabular}

L: linear, V: convex, C: concave. VL means the slope surface has straight width and curved length. VV means the slope surface has curved length and curved width.

${ }^{\text {a }}$ Slope shape: the category of geometric forms on the hill slope was followed the suggestions of Ruhe (1975). 
peripheral parts, where the slope angle is considerably lower. The VV type is distributed mostly in the central part, where the slope angle is significantly higher.

\section{Methodology}

The investigation consisted two parts: (1) specific criteria for choosing the outcrops, (2) determination of gravel shapes, and (3) measurement of the dip direction of the gravel.

Outcrops were chosen carefully in order to provide consistent variables on which to base the correlation analysis of the gravel slopes. The slope attitudes at 92 outcrop sites were measured. The Canshi area contains 32 sites, the Tienwekenshi, Yuncheukenshi, and Shendonzekenshi areas each contain 20 sites.

Thirty pocket penetrations were tested in the gravel matrices at each studied outcrop site. The matrices were bonded so thoroughly and tightly that they were impossible to dislodge without destroying them in the process. Penetration tests were then executed in the field, and correlations were run on all the samples measured. At least $2 \mathrm{~cm}$ of space between gravel pieces was used as the minimum space necessary to ensure that the true measure of the strength of the matrix bond was uncontaminated by the proximity of the gravel fragments.

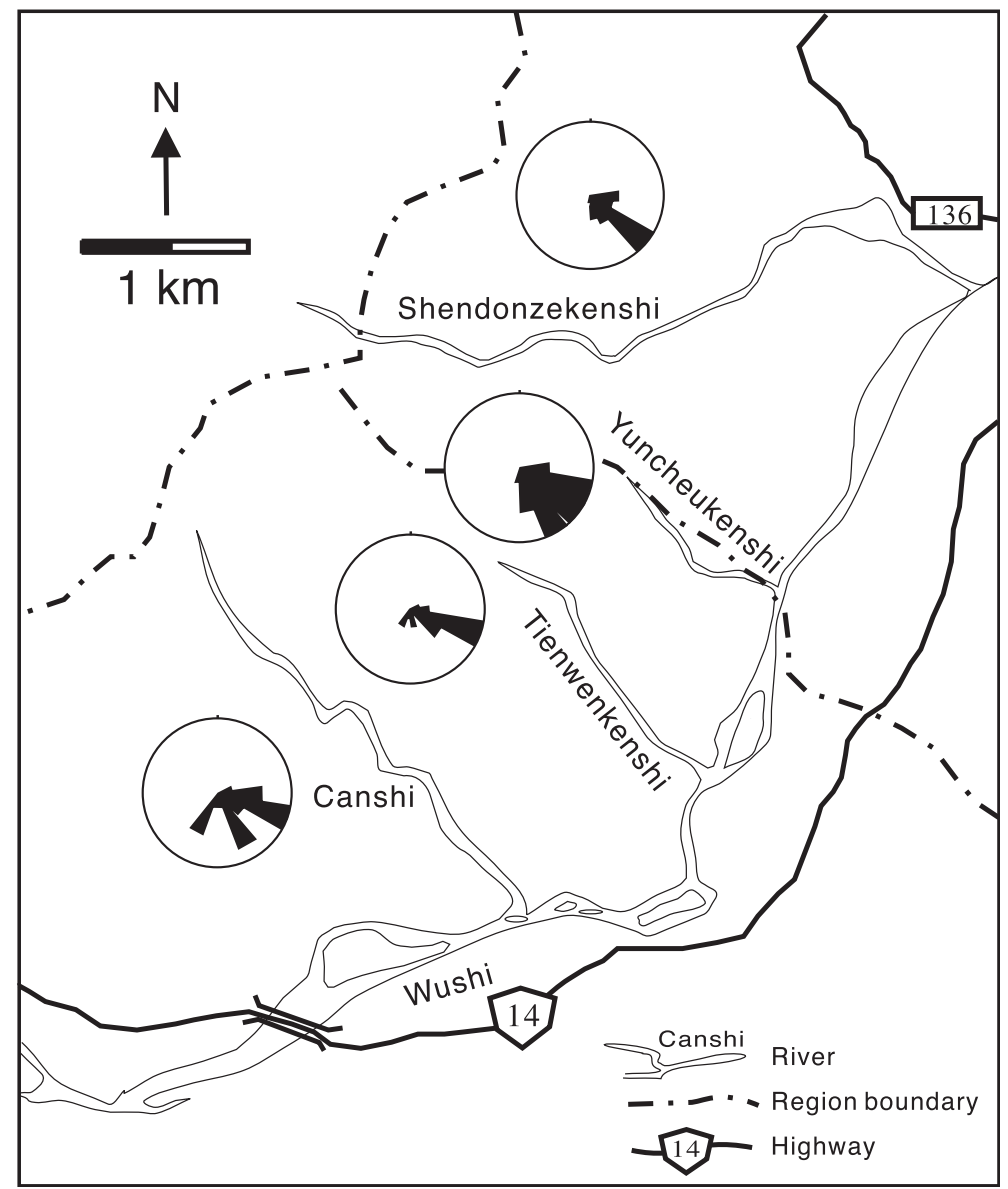

Fig. 5. Rose diagram showing that the imbrication of the gravel orientation is highly regular in the study area. 
Gravel shapes were determined along the three standard dimensions or axes. These were designated $d_{\mathrm{L}}$ for the longest axis, $d_{\mathrm{I}}$ for the middle axis and $d_{\mathrm{S}}$ for the shortest axis. These shape measurement on the sites were randomly chosen from fresh outcrops of the slopes. The measurements also included the imbrication direction and imbrication of the maximum plane (containing $d_{\mathrm{L}}$ and $d_{\mathrm{I}}$ ) in the bladed gravel at the fresh slope surface. The imbrication direction was taken to represent the trend for a maximum plane that the gravel displays at the slope surface. Slope attitude data and gravel orientation were measured and plotted on a standard Schmidt stereonet projection. This produced a combined overall orientation.

Thin-section analyses of the gravel samples and $\mathrm{X}$-ray diffraction clay mineral identification of the matrix from the four different sites were carried out. Gravel size distribution was analyzed according to percentage by weight in three fractions. One part covered gravel sizes over $15.5 \mathrm{~mm}$, another part covered gravel sizes less than $15.5 \mathrm{~mm}$, the third part covered particles smaller than $2 \mathrm{~mm}$. These measures by weight were combined for calculate a final particle size distribution.

\section{Results}

The rose diagrams show that the imbrication direction of the gravel is highly regular in the study area (Fig. 5). Most of the dip directions range between $80^{\circ}$ and $220^{\circ}$. More than $80 \%$ of the dip directions of the gravels were distributed between $120^{\circ}$ and $140^{\circ}$. Gravel imbrications are thus NW-SE.

The classification of gravel shapes using Zingg's shape method (Zingg, 1935) shows four different shapes, namely, disk, bladed, roller, and equant (Fig. 6). Measurements of the long, middle, and short axes of gravel were further analyzed by considering the ratios $d_{\mathrm{I}} / d_{\mathrm{L}}$ and $d_{\mathrm{S}} / d_{\mathrm{I}}$.

Slope angles are shown in Table 2. The average slope is $67^{\circ}$. The distribution of slope aspect is rather random. There is a slight concentration of aspect within the ranges of aspect, $10-50^{\circ}$ and $100-160^{\circ}$ are less than $40 \%$ of the total area. This means that the slope aspect is still quite random in the study area (Fig. 7).

Most gravel shapes are disks (Fig. 8) with frequency ranging from $24 \%$ to $58 \%$ with an average of

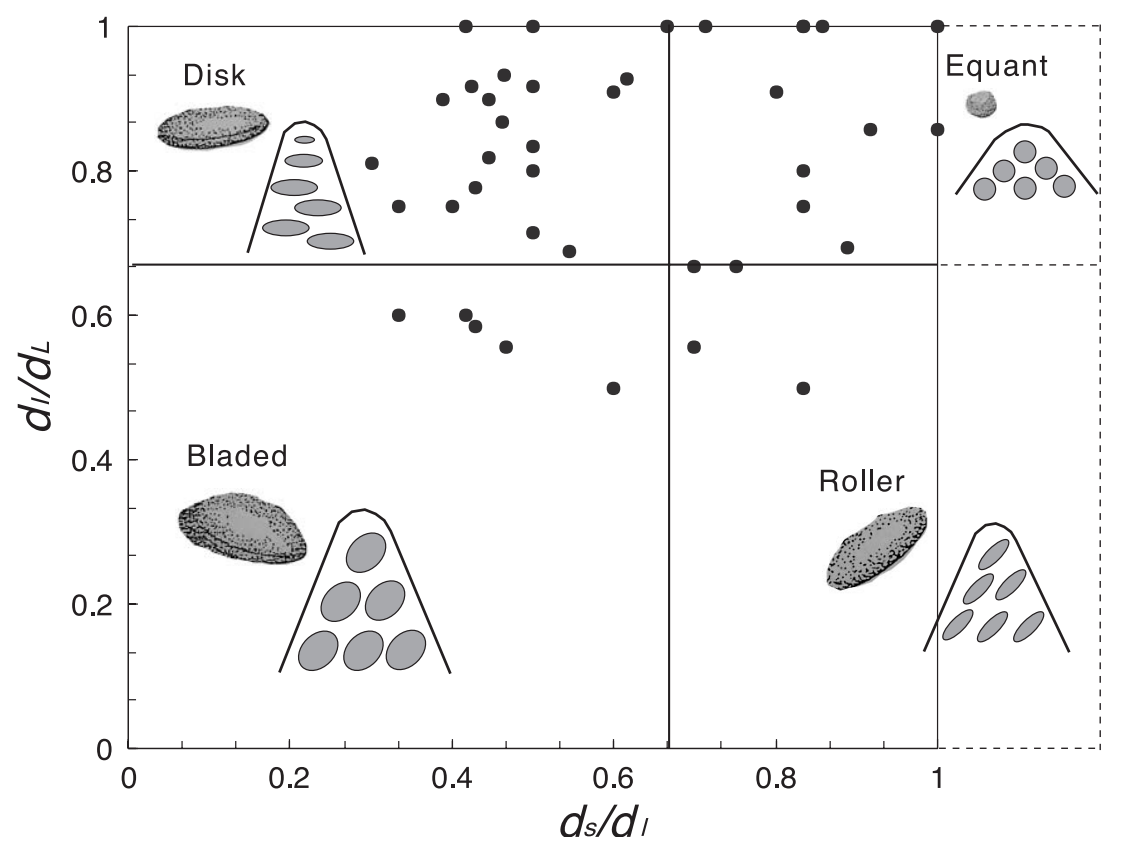

Fig. 6. Zingg's diagram revealing various gravel shape compositions in the study area. 
Table 2

Distribution of the slope angle in the study area

\begin{tabular}{llllll}
\hline & All area & Canshi & Tienwenkenshi & Yuncheukenshi & Shendonzekenshi \\
\hline Slope angle $\left({ }^{\circ}\right)$ & $52-85$ & $55-82$ & $52-85$ & $55-85$ & $52-76$ \\
Average $\left({ }^{\circ}\right)$ & 66 & 67 & 64 & 67 & 65 \\
\hline
\end{tabular}

$40 \%$. Equant content ranges from $13 \%$ to $58 \%$, with an average of $33 \%$. Bladed and roller shapes make up a minority and have an average of only $12 \%$ and $16 \%$, respectively.

The intersected angle is defined to mean the angle between the gravel imbrication direction and the slope surface. The imbrication strike trend is defined to be the line of intersection of the plane of gravel imbrication with the slope surface. Nearly $80 \%$ of the intersected angles were between $30^{\circ}$ and $90^{\circ}$ (Fig. 9).

The gravel composition is around $90 \%$ quartzite. The maximum diameter of a mineral particle is around $3 \mathrm{~mm}$. The results of X-ray diffraction reveal that the clay minerals of the matrix include quartz, kaolinite, illite, and minor smectite. The distribution percentage by weight of particles size over $2 \mathrm{~mm}$ is $85.2 \%$. The percentage by weight of particles sized $0.074-2 \mathrm{~mm}$ is

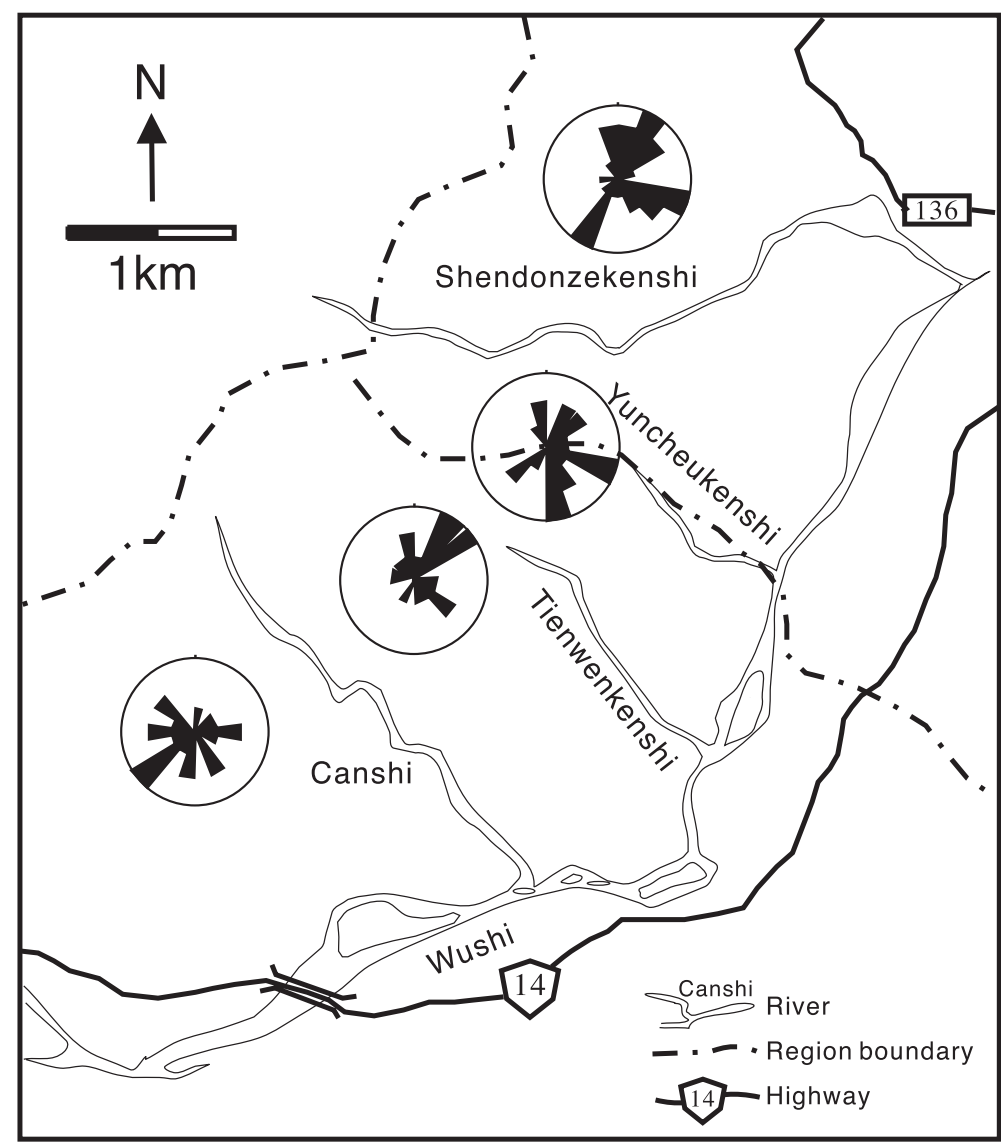

Fig. 7. Rose diagram showing the imbrication direction of the slope surface has a random distribution. 


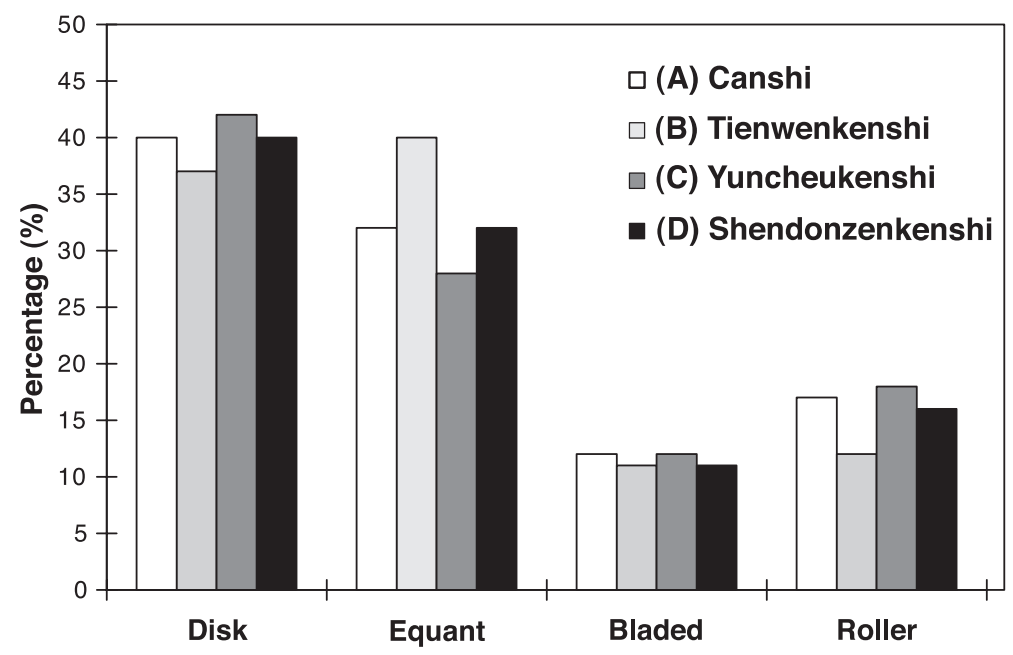

Fig. 8. The disk shape is a majority composition in gravel formation of the study area.

$13.6 \%$. The percentage by weight of particles sized under $0.074 \mathrm{~mm}$ is only $1.2 \%$. Therefore, sand and fine fractions form the matrix content in most of the conglomerate.

Physical properties and penetration strength of the matrix were measured. The specific gravity is 2.52. The plastic limit is $15 \%$, and the liquid limit is $26 \%$. The plasticity index is 11 . The classification of the matrix is silty sand (SM). There is only minor difference among the four sites. The in situ results of penetration strength show that all the matrices range from 100 to $250 \mathrm{~kg} / \mathrm{cm}^{2}$, a range that can be classified as weak rock (R2) in the International Society of Rock Mechanics (1981) catalogue.

\section{Statistical analysis}

The intersected angles between imbrication direction and slope surface were plotted using a stereonet projection. Statistical analyses of the relationships between gravel orientation and slope surface were carried out.

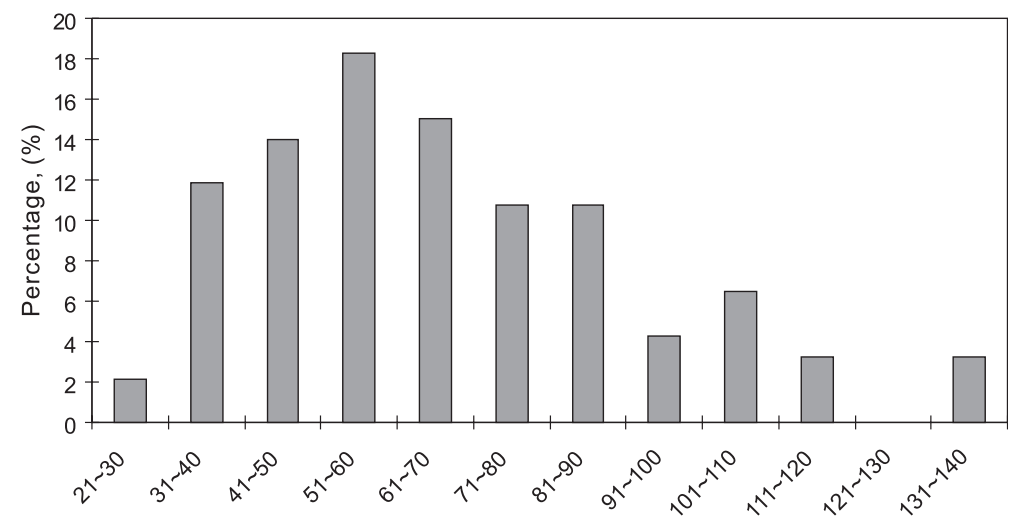

Angle of intersection between gravel imbrication and slope surface (degr.)

Fig. 9. A total of $80 \%$ of the angles between gravel imbrication and slope are between $30^{\circ}$ to $90^{\circ}$. 


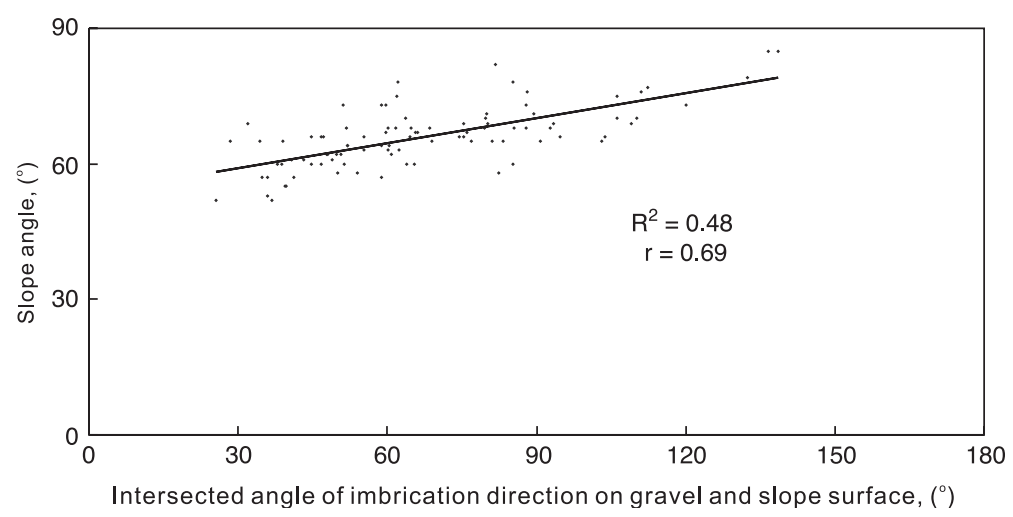

Fig. 10. A linear trend displays a significant correlation and positive relationship between the intersected angle of imbrication direction on the gravel and slope surface.

The results at the four sites show that the slope angle varies with the intersection angle between the imbrication and slope surface. It appears, however, that the imbrication direction of the gravel is fairly regular. Fig. 10 shows that the slope angle increases with the intersected angle. These results reveal a positive, linear trend between slope and intersected angle with a correlation coefficient, $r$, of 0.69 .

The distribution of disk, equant, bladed, and roller grain shapes of gravel in the four sites were measured for comparison with the slope angle. The results for disk-shaped gravel (Fig. 11) show a
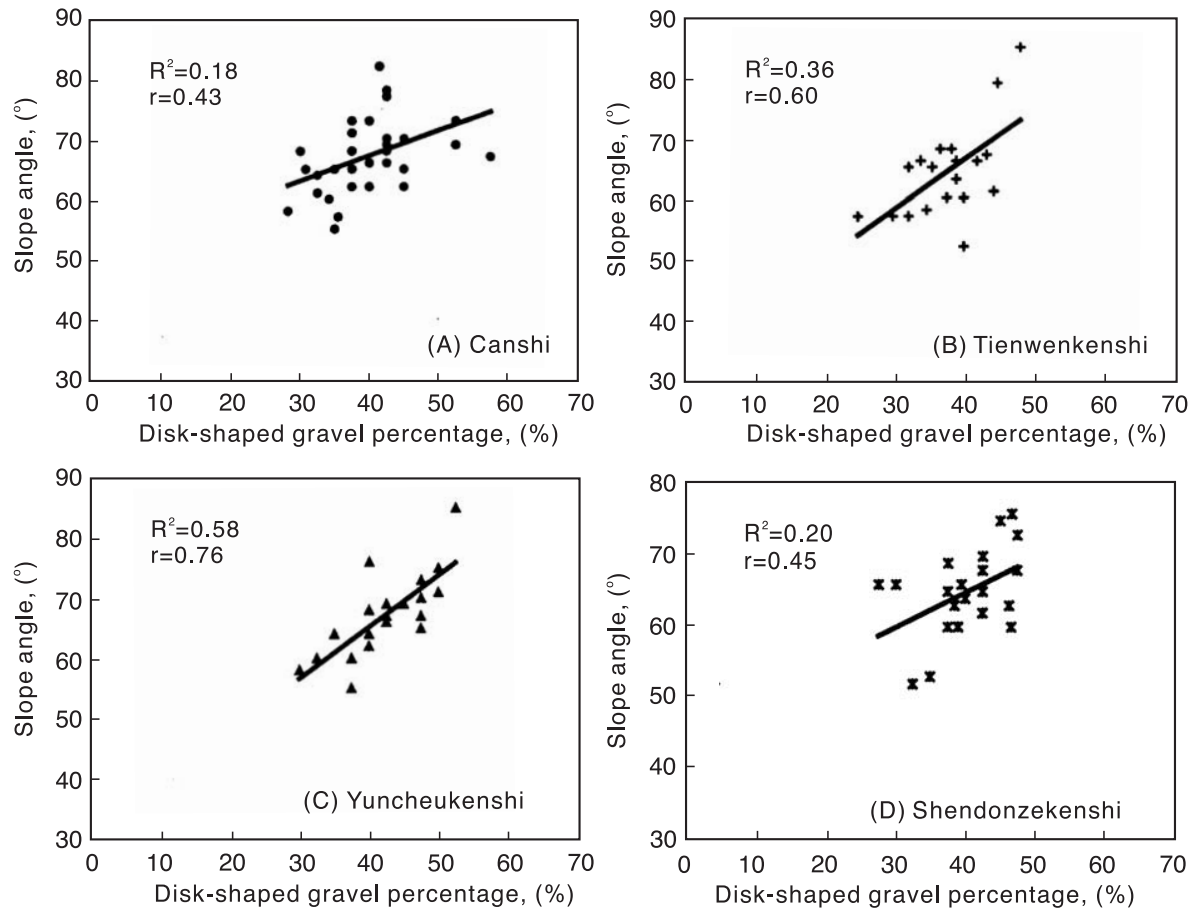

Fig. 11. The relationship between the disk shapes and slope grade displays a significant and positive correlation. 
moderate, positive, linear trend between slope and the proportion of disk-shaped gravel $(r=0.43,0.60$, 0.76 , and 0.45 ). In contrast, the data show a significant negative, linear trend between slope and the proportion of equant gravel clasts $(r=-0.65$, $-0.83,-0.77$, and -0.79$)$. Meanwhile, the two other shapes (bladed and roller) display a lower correlation coefficient with slope. In practical terms, the results demonstrate that the slope angle is strongly dependent on gravel clast shape. Higher slopes are found in gravel with a larger proportion of anisotropic clasts.

In order to avoid the misinterpretation of the diagram, data were averaged in $3^{\circ}$ interval bins. In this study, slope angles ranging from $51^{\circ}$ to $86^{\circ}$ were divided into 12 bins, each bin being $3^{\circ}$ wide. The results (Fig. 12) reveal clear linear relationships be- tween gravel and slope angles, all of which displayed high correlation coefficients $(r=0.85,-0.96,0.93$, and 0.92).

\section{Discussion}

In general, the actual dip direction of gravel orientation should be measured after adding the bedding correction for the study area (Potter and Pettijohn, 1963). The in situ investigation found that some of the gravel formations were only rarely interbedded with sandstone with dip angle ranges from $10^{\circ}$ to $20^{\circ}$ in the study area. This is in line with the results of Yang (1986), which found similar relationships in the uplift stratigraphy in central Taiwan. He also pointed out that the dip
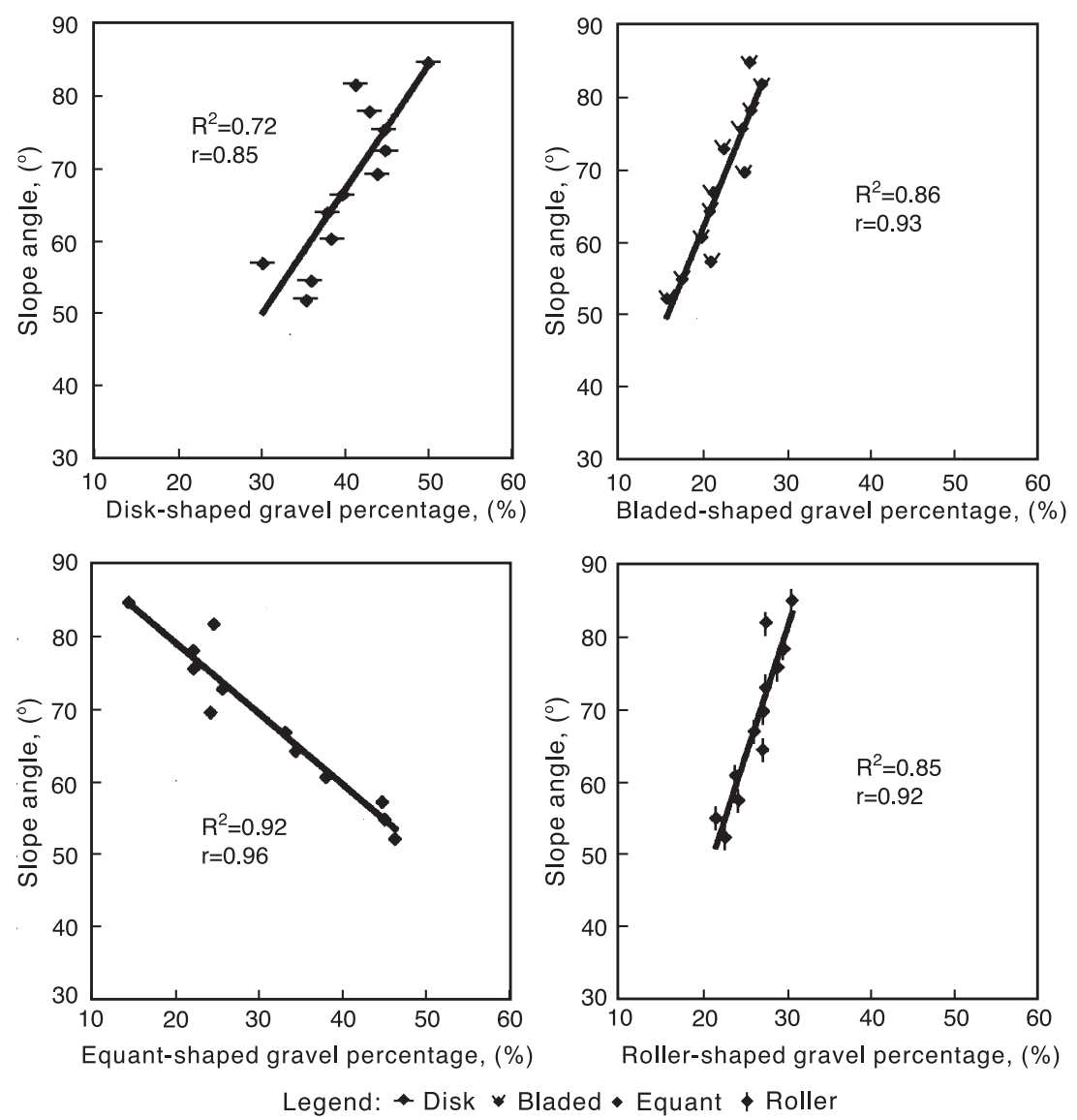

Fig. 12. The average results were obtained from the slope grade with a $3^{\circ}$ measurement interval. 
direction of gravel formation did not change during the uplift procedure of stratigraphy. Consequently, the evidence with regard to the dip direction in the gravel orientation could indicate the paleocurrents direction of the Ninety-Nine Peaks.

The in situ results for matrix strength reveal that the cementation is very much evident in the gravel formation. This suggests that the gravel formation remains imbricate when the shear strength is transferred from the gravel particles to the matrix support during the consolidation. Vallejo (2001) demonstrated that when concentration of coarse grains is greater than $70 \%$, the mixture structure is controlled by coarse particles. This means that the shear strength was governed by the gravel content directly and is not affected by the matrix content (Chen and Chen 1991; Day 1993). Furthermore, this is the reason why the distribution of gravel shapes can be a factor in determining the slope angle.

The revised presentation method using a $3^{\circ}$ interval measurement may very well make for less imprecision. In practical terms, the intersection of gravel orientation with the slope surface was examined by the above method to understand better the effects of gravel orientation on the slope surface. Nonetheless, gravel orientation was found to exert much more influence than gravel shape on slope angle.

\section{Concluding remarks}

1. The average slope angle is around $66^{\circ}$ and more than $65 \%$ of the gravel is composed of disk and equant shapes.

2. The sediment characteristics in the gravel formation are quite uniform and do not affect the relationship between slope angle and gravel shape and orientation.

3. The field results demonstrate that slope angle steepens as the gravel displays a higher anisotropy. When the gravel imbrication is random and rarely uniform, the gravel is more isotropic.

4. The data show strong correlation between clast shape and slope angle, indicating that the different shapes and orientations of grains will affect the slope angle.

\section{Acknowledgements}

The National Science Council, ROC, and Endemic Species Research Institute, Agriculture Council, supported this research project financially. The authors would like to thank S.J. Dadson, S.E. Poynter, K. Thompson, J.C. Lin, R.H. Chen and L. Teng and two anonymous reviewers for their constructive comments and help in writing this manuscript. Thanks are also extended to C.M. Yu and I.G. Chi for improving the figures.

\section{References}

Chen, H., Chen, R.H., 1991. Some engineering characteristics of Quaternary geology in Northern Taiwan. Acta Geol. Taiwanica 29, 179-191.

Chen, W.F., Teng, L.S., 1990. Depositional environment of Quaternary deposits of the Linkou tableland, northwestern Taiwan. Proc. Geol. Soc. China 33 (1), 39-63.

Chen, H., Tsai, B.R., 2002. The relationship between slope gradient and lateritic cobble orientation with respect to shape, northwestern Taiwan. Environ. Geol. 42 (3), 1-17.

Chou, C.Y., 1977. Sedimentary and paleogeography of the Pleistocene Toukoshan Formation in Western Taiwan. Pet. Geol. Taiwan $14,25-36$

Day, R.W., 1993. The engineering behavior of a natural deposit of gravels. Bull. Int. Assoc. Eng. Geol. 30 (2), 213-254.

Ho, C.S., 1986. An Introduction to the Geology of Taiwan: Explanatory Text for the Geologic Map of Taiwan. Ministry of Economic Affairs, Republic of China, pp. 15-48.

International Society of Rock Mechanics, 1981. Site characterization. In: Brown, E.T.Rock Characterization Testing and Monitoring. Pergamon, London, pp. 30-35.

Nemec, W., Steel, R.F., 1984. Alluvial and coastal conglomerates: their significant features and some comments on gravelly massflow deposits. In: Koster, E.H., Steel, R.J.Sedimentology of Petroleum Geologists Memoir, vol. 10, pp. 1-31.

Potter, P.E., Pettijohn, F.J., 1963. Paleocurrents and Basin Analysis Springer-Verlag, Berlin (296 pp.).

Ruhe, R.V., 1975. Geomorphology: Geomorphic Processes and Surficial Geology. Houghton Mifflin, Boston, pp. 99-101.

Teng, L.S., 1996. Extensional collapse of the northern Taiwan mountain belt. Geology 24, 949-952.

Tsai, B.R., 1996. The effects of gravel grade with gravel orientation and shape in terrace formation of northwestern Taiwan. MSc thesis, National Taiwan University. 105 pp. (in Chinese).

Vallejo, L.E., 2001. Interpretation of the limits in shear strength in binary granular mixtures. Can. Geotech. J. 38, 1097-1104.

Vallejo, L.E., Mawby, R., 2000. Porosity influence on the shear strength of granular material-clay mixture. Eng. Geol. 58, $125-136$.

Wagner, A.A., 1957. The use of the unified soil classification system by the bureau of reclamation. Proc. 4th International 
Conference Soil Mechanics Foundation Engineering, London, vol. I, pp. $125-126$

Wang, W.S., 2001. The relationship between the gravel textures, shear strength with slope stability in western part of Taiwan. PhD thesis, National Taiwan University. 395 pp. (in Chinese).
Yang, K.S., 1986. Topographical study of Taiwan active fault- the relationship between the active fault and topography. $\mathrm{PhD}$ thesis, Chinese Culture University. 178 pp. (in Chinese).

Zingg, Th., 1935. Beitrage-zur Schotter analyse: mineral petrology. Mitt. Schweiz., 39-40. 